DOE/MA-0012

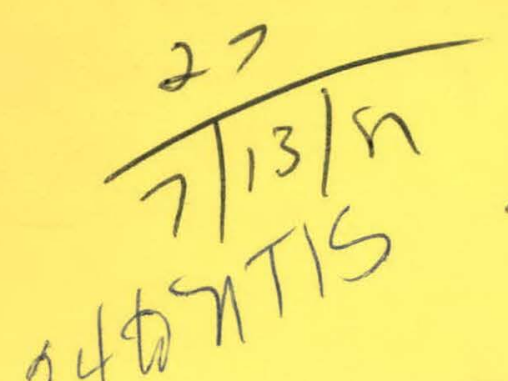

$B 5559$

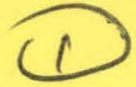

\title{
A Guide to Preparation of Department of Energy Procurement \& Financial Assistance Planning Forms
}
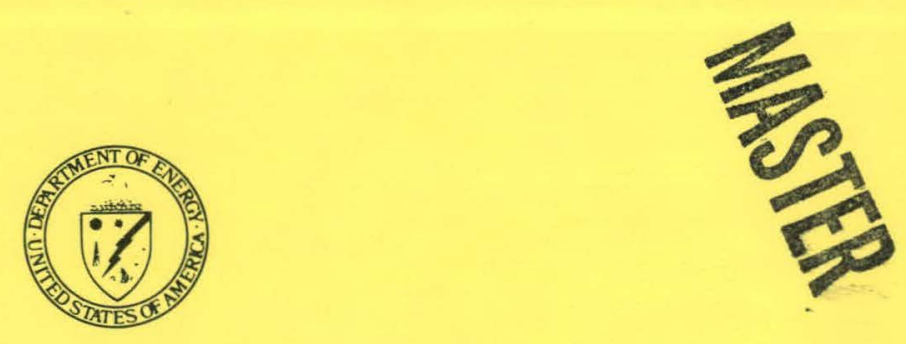

July 1981

\author{
U.S. Department of Energy \\ Assistant Secretary for Management and Administration \\ Procurement and Assistance Management
}




\section{DISCLAIMER}

This report was prepared as an account of work sponsored by an agency of the United States Government. Neither the United States Government nor any agency Thereof, nor any of their employees, makes any warranty, express or implied, or assumes any legal liability or responsibility for the accuracy, completeness, or usefulness of any information, apparatus, product, or process disclosed, or represents that its use would not infringe privately owned rights. Reference herein to any specific commercial product, process, or service by trade name, trademark, manufacturer, or otherwise does not necessarily constitute or imply its endorsement, recommendation, or favoring by the United States Government or any agency thereof. The views and opinions of authors expressed herein do not necessarily state or reflect those of the United States Government or any agency thereof. 


\section{DISCLAIMER}

Portions of this document may be illegible in electronic image products. Images are produced from the best available original document. 


\section{INTRODUCTION}

A procurement and Federal assistance planning system is vital to effective and efficient management of the Department of Energy's mission. The planning system is essential to the procurement and Federal assistance process. It gives Departmental managers and the procurement community information on how DOE plans to do business in the next fiscal year as well as the extent of competition in the Departmental procurement process. Planning information is used to forecast procurement workload and plans for increased competition. Good planning can be a tool to efficiently manage resources in order to expedite the timely acquisition of equipment and contractual services and continue the Department's mission.

Planning is the first step in the procurement and financial assistance process and the Integrated Procurement Management Information System (IPMIS). Therefore, it is essential that planning forms are accurately completed and updated to provide the initial source data for planned procurement and assistance transactions

The complete "Guide to Preparation of Department of Energy Procurement and Financial Assistance Planning Forms" was revised to incorporate the latest changes in IPMIS. This "Guide" and a memorandum which officially requests DOE offices to submit planning forms for all planned procurement and assistance transactions provide instructions for completing the forms and other information relative to fulfulling this requirement.

The planning forms are DOE F-4200.6, DOE-F-4200.7 and DOE-F-4200.8. These forms and this "Guide" can be obtained from any Headquarters supply store, regional offices, operations offices, energy research centers, project of fices and power administrations. 
PAGE NO.

SECTION 1

General

Part A - General Instructions

Part B - Blank Forms - DOE-F-4200.6

- DOE-F-4200.7

- DOE-F-4200.8

SECTION 2

Initiating Plans for New Awards and Modifications to Existing Awards

Part A - Detailed Instructions for Completing DOE $-\mathrm{F}-4200.6$

Part B - Detailed Instructions for Completing DOE $-\mathrm{F}-4200.7$

SECTION 3 Initiating Field Work Package Proposal and Authorization System (WPAS) Summary Plans

Part A - Detailed Instructions for Completing DOE $-F-4200.6$

Part B - Detailed Instructions for Completing DOE $-\mathrm{F}-4200.7$

Part C - Updating WPAS Summary Plans

SECTION 4

Updating or Correcting Plans

Part A - Detailled Instructions for Correcting DOE-F -4200.6

Part B - Detailed Instructions for Correcting DOE-F -4200.7

SECTION 5

Cancellations

Part A - Detailed Instructions for Cancelling a Plan

APPENDIX, A Initiating Organizations 


\section{SECTION 1}

Part A - GENERAL INSTRUCTIONS

The planning forms (DOE-F-4200.6, DOE-F-4200.7, and DOE-F 4200.8) provide the source data for the planning data elements in the Integrated Procurement Management Information System (IPMIS).

Al1 procurement and assistance transactions in excess of $\$ 10,000$ must be planned. Initiating offices are to submit their plans in advance of the new FY, as directed in Departmental planning call memoranda. These transactions are to be planned regardless of their sources of funds (i.e., appropriated, carry-over, revenue or reimbursable work for others) or the types of funds used (i.e., operating or plant and capital equipment).

DOE-F-4200:6 must be completed for each new planned procurement or assistance action. It is also the basic source document for a modification or an incremental funding action to an existing award, and the Field Work Package Proposal and Authorization System (WPAS) Summary Plans.

DOE-F-4200.7 is to be used for supplemental planning information if any of the following conditions exist:

- If there are more than three Budget and Reporting (B\&R) Numbers, or Headquarters initiating office codes.

- If there is to be incremental funding during the current fiscal year.

- If the plan is for a loan or loan guarantee financial assistance transaction.

DOE-F-4200.8 is only: to be used to cancel a planning record.

The planning forms in Part B are the current forms. All shaded data elements are to be left blank. These shaded elements will not be included on the final planning forms. The Appropriation Symbol, though not shaded, is to be left blank. Zero dollar plans (no dollar plans) and negative dollar plans will not be allowed.

All dollar amounts are to be reported in whole dollars as they are required to be reported on the Procurement Request and award documents.

All plans must contain elther a valld B\&R number or a valid Headquarters initating office code in the $B \& R$ number field for all current FY dollar amounts.

The Product or Service Codes on the back of the DOE-F-4200.6 form are no longer valid. Refer to APPENDIX $C$ for the valid list of Product or Service Codes. 
Due to reorganizations within the Department, several offices have changed initiating office code symbols. For example, offices which were previously under CS are now within CE and EP. There are two general numbering rules to follow:

1. To initiate a plan for a new award (when no basic award exists), use your current organizational initiating office symbol and obtain a register number from your office's register to formulate the IPMIS NUMBER which is entered on the planning forms.

2. To initiate a plan to modify an existing contract or grant, use the same seven-position register number which is contained in the contract number (Business Instrument Number) to formulate the IPMIS Number which is entered on the planning forms.

Note that these forms are designed to be filled in with an elite (12 characters per inch) typewriter and the appropriate number of spaces is available in each blank to enter the typewritten information in capital letters. If a typewriter is not available, print the information in capital letters.

Part B - Blank Forins

DOE $-F-4200.6$

DOE $-F-4200.7$

DOE $-F-4200.8$

follow on pages $3-6$. 


\begin{tabular}{|c|c|c|c|c|}
\hline 1. INITIAL: [ ] UPD, & 1 & & \multicolumn{2}{|c|}{ 2. PROCUREMENT [ ] FINANCIAL ASSISTAANCE } \\
\hline 3. PREPARATION DATE & Mont & Yoar & \multicolumn{2}{|l|}{ 4. IPMIS NUMBER:- } \\
\hline \multicolumn{5}{|l|}{ INITIATOR } \\
\hline \multirow[t]{2}{*}{ 5. PROJECT MANAGER: } & & & & \multirow[t]{3}{*}{ 6. OFFICE CODE: } \\
\hline & Last, & First, & Middle I. & \\
\hline \multicolumn{4}{|c|}{ 7. TELEPHONE NUMBER: } & \\
\hline
\end{tabular}

8. TITLE:

9. CFDA NO:

11. PRODUCT OR SERVICE:

13. CONSULTANT AWARD: YES AWARD PLANNING

14. PLANNED AWARDING OFFICE:

16. SOURCE SELECTION PROCEDURE:

$1-\mathrm{A}-\mathrm{E}$
10. 189/TAPS NO.:

12. SUPPORT SERVICES: YES NO

17. FOR A-E, SHOW ESTIMATED CONSTRUCTION COSTS IN THOUSANDS OF DOLLARS:

18. TYPE SOLICITATION INSTRUMENT:

AWARDEE IF NON-COMPETITIVE, COMPLETE THIS SECTION

20. NAME:

21. DIVISION:

FINANCIAL

AWARD VALUE

\$ AMOUNT

Whole Dollars

23. GOVT SHARE:

24. TOTAL:

CONSIDERATION IN KIND, LOAN, AND LOAN GUARANTEE DATA REPORTED ON PR -XXXB: [ ]

25. APPROPRIATION SYMBOL:

26. ALLOTMENT SYMBOL:

*See back of form for codes.
19. PR INITIATION DATE:

22. GOCO/LAB

FUNDING SOURCE

BER NUMBER

$\$$ AMOL'NT

Whole Dollars

27. CURRENT FY $\dagger_{-}-\quad 28$.

CURRENT FY

CURRENT FY

29. CURRENT FY FROM PR $-X X X B$

30. CURRENT FY TOTAL

31. NEXT FY TOTAL

32. ALL OTHER TOTAL
$A-G O C O / L A B$

$B-G O C O / N O N-L A B$

C-NON-GOCO/LAB

D-NOT APPLICABLE 
DOE FORM PR - XXXA (TEST) (BACK)

PROCUREMENT DATA/FINANCIAL ASSISTANCE PLAN

11. PRODUCT OR SERVICE

\begin{tabular}{|c|c|c|}
\hline CODE & $\frac{\text { MEANING }}{\text { RED SERVICES }}$ & CODE \\
\hline 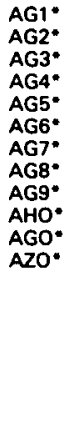 & $\begin{array}{l}\text { COAL } \\
\text { GAS } \\
\text { GEOTHERMAL } \\
\text { HYDRO } \\
\text { NUCLEAR } \\
\text { PETROLEUM } \\
\text { SOLAR } \\
\text { CONSERVATION OF ENERGY } \\
\text { OTHER ENERGY } \\
\text { ENVIRONMENT } \\
\text { GENERAL SCIENCE \& TECHNOLOGY } \\
\text { OTHER RED } \\
\text { REPLACE - WITH: } \\
\text { B-BASIC \& APPLIED RESEARCH } \\
\text { X-EXPLORATORY DEVELOPMENT } \\
\text { T-TECHNOLOGY DEVELOPMENT } \\
\text { E-ENGINEERING SYSTEMS DEV. } \\
\text { S-OPERATIONAL SYSTEMS DEV. } \\
\text { C-COMMERCIALIZATION }\end{array}$ & $\begin{array}{l}\text { JOOO } \\
\text { KOOO } \\
\text { LOOO } \\
\text { MOOO } \\
\text { NOOO } \\
\text { R100 } \\
\text { R200 } \\
\text { R300 } \\
\text { R400 } \\
\text { R500 } \\
\text { R600 } \\
\text { SOOO } \\
\text { YOOO } \\
\text { ZOOO }\end{array}$ \\
\hline
\end{tabular}

MEANING

SERVICES OTHER THAN RGD MAINTENANCE \& REPAIR EQUIPMENT MODIFICATION OF EOUIPMENT TECHNICAL REPRESENTATIVE SERV. TECHNICAL REP ESENTATIVE SERV. OPERATION OF GOVERNMENT INSTALLATION OF EQUIPMENT ARCHITECT \& ENGINEER - CONST ARCHITECTS \& ENGINEERS - GEN. AUTMATIC DATA PROCESSING SERV MANAGEMENT \& PROFESSIONAL SERV. SPECIAL STUDIES G ANALYSES SER. UTILITES \& HOUSEKEEPING SERV. MAINTENANCE \& REPAIR STRUCTURES
CODE MEANING

PRODUCTS (SUPPLIES \& EQUIP.)

NUCLEAR ORDNANCE

SPECIAL INDUSTRY MACHINERY

CONSTRUCTION \& MINING EQUIPMENT

FURNACE, STEAM, NUCLEAR REACTORS

PLUMBING, HEATING, SANITATION EQUIP.

PLUMBING, HEATING, SANITATION EQUIP,

ELECTRICAL G ELECTRONIC EQUIP. COMPONENTS

ELECTRICAL $\&$ ELECTRONIC EQUIP. COMPONE
ELECTRIC WIRE \& POWER DISTRIB. EQUIP.

ELECTAC WIRE \& POWER DISTRIB. EOUP.

INSTRUMENTS \& LABORATORY EQUIP.

ADP EQUIPMENT, SOFTWARE, SES EQUIP.

ADP EQUIPMENT, SOFTWARE, SES

FUELS, LUBAICANTS, OILS, WAXES ORES E MINERALS \& THEIR PRODUCTS
MISCELLANEOUS

14. PLANNED AWARDING OFFICE

\begin{tabular}{|c|c|c|}
\hline \multicolumn{2}{|c|}{ CODE } & MEANING \\
\hline $\begin{array}{l}04 \\
02 \\
13 \\
07 \\
08 \\
05 \\
06 \\
03 \\
09 \\
01\end{array}$ & $\cdot$ & $\begin{array}{l}\text { ALBUQUERQUE } \\
\text { CHICAGO } \\
\text { GRAND JUNCTION } \\
\text { IDAHO } \\
\text { NEVADA } \\
\text { OAK RIDGE } \\
\text { RICHLAND } \\
\text { SAN FRANCISCO } \\
\text { SAVANNAH RIVER } \\
\text { WASHINGTON } \\
\text { PROJECT OFFICES }\end{array}$ \\
\hline & & $\begin{array}{l}\text { CLINCH RIVER BREEDER REACTOR } \\
\text { FAST FLUX TEST FACILITY } \\
\text { STRATEGIC PETROLEUM RESERVE } \\
\text { POWER ADMINISTRATION }\end{array}$ \\
\hline $\begin{array}{l}85 \\
79 \\
70 \\
75\end{array}$ & & $\begin{array}{l}\text { ALASKA } \\
\text { BONNEVILLE } \\
\text { SOUTHEASTERN } \\
\text { SOUTHWESTERN } \\
\text { WESTERN AREA }\end{array}$ \\
\hline
\end{tabular}

\begin{tabular}{ll} 
CODE & MEANING \\
\cline { 1 - 2 } 41 & REGIONAL OFFICES \\
42 & REIION I, BOSTON \\
42 & REGION II, NEW YORK CITY \\
43 & REGION III, PHILADELPHIA \\
44 & REGION IV, ATLANTA \\
45 & REGION V, CHICAGO \\
46 & REGION VI, DALLAS \\
47 & REGION VII, KANSAS CITY \\
48 & REGION VIII, DENVER \\
49 & REGION IX, SAN FRANCISCO \\
51 & REGION X, SEATTLE \\
& ENERGY RESEARCH CENTERS \\
19 & BARTLESVILLE \\
18 & GRAND FORKS \\
20 & LARAMIE \\
21 & MORGANTOWN \\
22 & PITTSBURGH
\end{tabular}

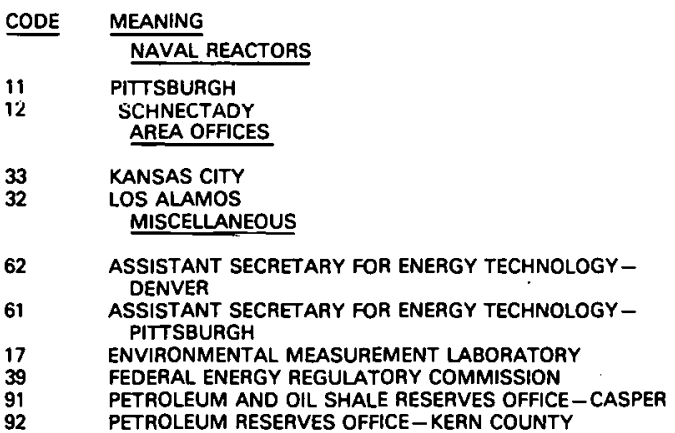

15. EXXTENT OF CUMPEIIIIIUN

\begin{tabular}{|c|c|}
\hline CODE & MEANING \\
\hline & PROCUACMENT SERIES \\
\hline \multirow[t]{2}{*}{ AA } & COMPETITIVE-UNRESTRICTED \\
\hline & COMPETITIVE-RESTRICTED \\
\hline \multirow[t]{2}{*}{ BE } & SMALL BUSINESS TOTAL SET-ASIDE \\
\hline & NON-COMPETITIVE \\
\hline $\mathrm{CC}$ & 8(a) PROGRAM \\
\hline $\mathrm{Co}$ & OTHER NEGOTIATION NON - COMPETITIVE \\
\hline \multirow[t]{2}{*}{ DC } & OTHER FEDERAL GOVERNMENT \\
\hline & MISCELLANEOUS \\
\hline EC & $\begin{array}{l}\text { USE ONLY FOR PROCU } \\
\text { SOMPETITION HAS NOI }\end{array}$ \\
\hline
\end{tabular}

\section{CODE MEANING}

FINANCIAL ASSISTTANCE SERIES

FA COMPETITIVE-UNRESTRICTED

GA COMPETITIVE-RESTRICTED

NON-COMPETITIVE

STATE GOVERNMENT

LOCAL GOVERNMENT

EDUCATIONAL INSTITUTION

INSTITUTION

OTHER NON - PROFIT INSTITUTION

SMALL BUSINESS

MINORITY BUSINESS

OTHER BUSINESS

INDIAN TRIBE

INDIVIDUAL

DIRECTED FINANCIAL ASSISTANCE FOR FOREIGN ENTITIES MISCELLANEOUS

IC UNKNOWN IUSE ONLY FOR FINANCIAL ASSISTANCE PLANNING ACTIONS WHERE EXTENT OF COMPETITION HAS NOT BEEN DETERMINED

18. TYPE SOLICITATION INSTRUMENT

\section{CODE MEANING}

FB INVITATION FOR BIDS (IFB)

NP NOTICE OF PRDGRAM INTEREST (NPI)

PA PROGRAM ANNOUNCEMENT

PN PROGRAM OPPORTUNITY NOTICE (PON)

RA PROGRAM RESEARCH \& DEVELOPMENT ANNOUNCEMENT (PRDA)

RI RESEARCH INVESTIGATION ANNOUNCEMENT (RIA)

RP REQUEST FOR PROPOSAL (RFP) 
U.S. DEPARTMENT OF ENERGY

PROCUREMENT/FINANCIAL ASSISTANCE PLAN - SUPPLEMENT

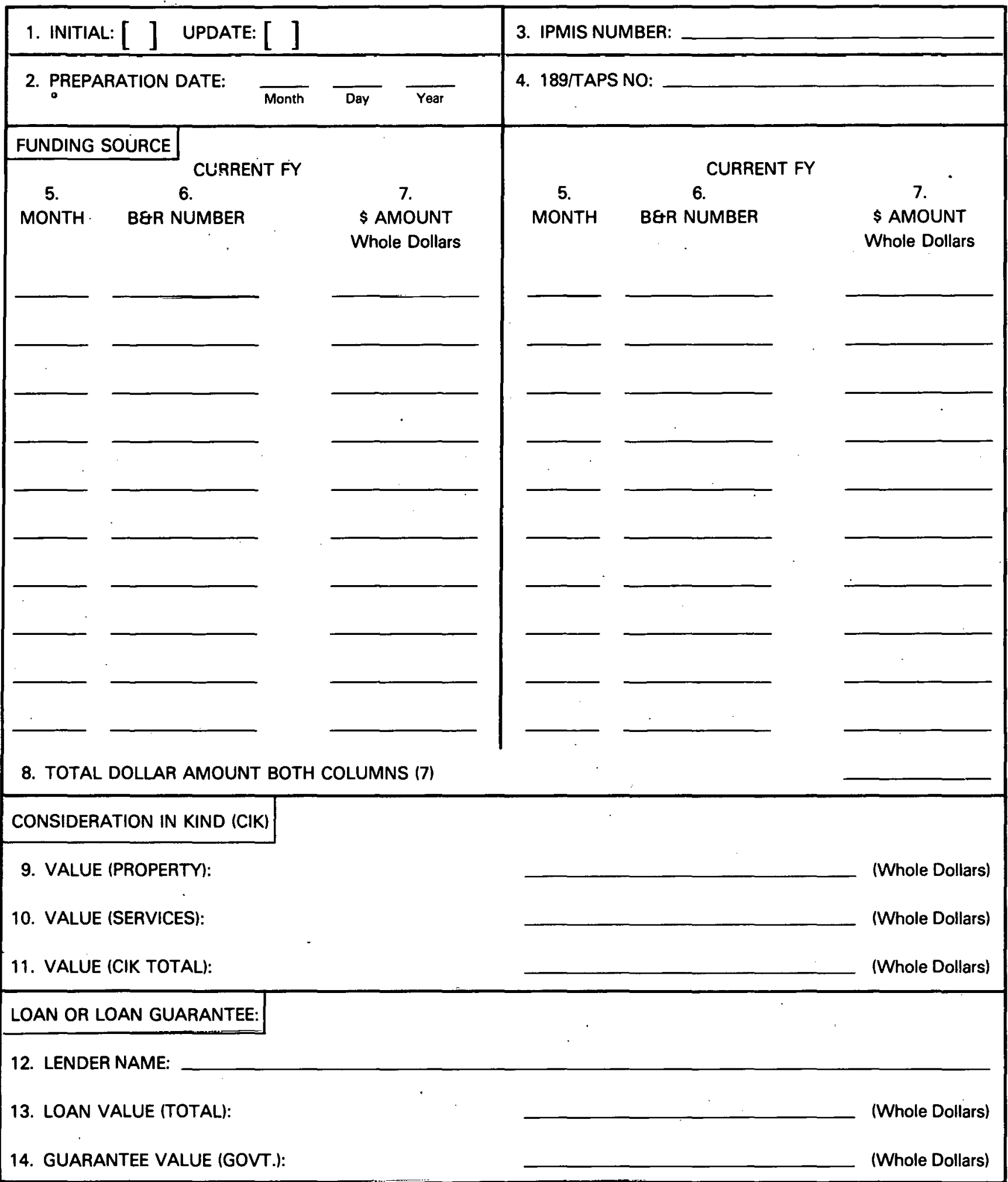


DOE-F 4200.8 (formerly PRXXXC).

(8-79)

U. S. DEPARTMENT OF ENERGY

PROCUREMENT/FINANCIAL ASSISTANCE PLAN-CANCELLATION

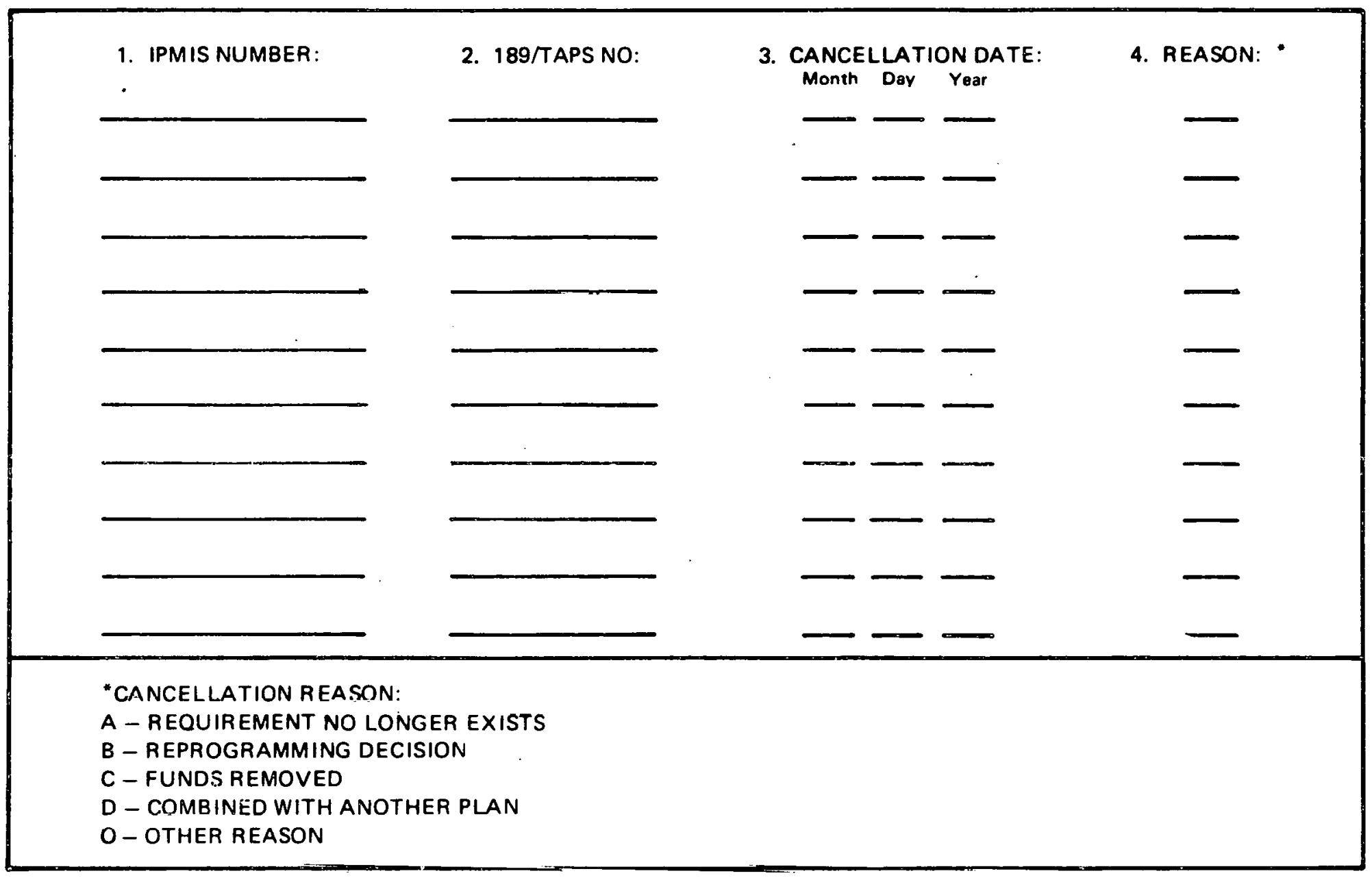


$\underline{\text { SECTION } 2}$

INITIATING PLANS FOR NEW AWAPDS AND MODIFICATIONS

TO EXISTING AWARDS

Part A - Detailed Instructions for Completing DOE-F-4200.6

The DOE-F-4200.6 contains 18 different data fields. Instructions for completing each field are given below in the same numerical sequence as they appear on the form.

All data elements described below are fields which must be completed when initiating a plan for a new award. THE PRODUCT OR SERVICE CODE (Item 11) is only to be filled in for procurement/acquisition type actions.

When initiating a plan to modify an existing award, the following data elements are to be left blank:

$\underline{\text { ITEM }}$

11. PRODUCT OR SERVICE

14. PLANNED AWARDING OFFICE

15. EXTENT OF COMPETITION

20. NAME (AWARDEE)

All other data elements are required.

1. INITIAL/UPDATE

Enter an $X$ in the box to the right of INITIAL for a new award or to modify an existing award. Check the update block only if a correction is to be made. See Section 4 for an explanation of updating/ correction procedures.

2. PROCUREMENT / FINANCIAL ASSISTANCE

Enter an $X$ in the box to the right of PROCUREMENT if this form covers a procurement or acquisition action which includes: Contracts, Spectal Research Contracts, Task Order/Project Agreements, Delivery Orders, and Interagency Agreements.

Enter an $X$ in the box to the right of FINANCIAL ASSISTANCE if this form covers any of the following types of financial or federal assistance: Cooperative Agreements, Grants, Interest Agreements, Loans, Loan Guarantees, Price Support Agreements and Subsidy Agreements . 
Enter the 13-character code which uniquely identifies this procurement or financial assistance action. This number is comprised of four parts: the fiscal year of the planned new award, or modification action, the initiating organization's register number, a decimal point, and an amendment number. An example of a valid IPMIS NUMBER is 81FE12345.000.

The first and second positions contain the last two digits of the fiscal year.in which the planned new award or modification action is to be funded, and must be equal to, or greater than, the current year.

The third through ninth positions contain the inftiating organization's register number which consists of the initiating organizational code and a unique serial number. The organizational register number is controlled within each Headquarters Secretarial and Staff office, operations office, project office, power administration, regional office, energy technology center or other equivalent field organizational office.

The tenth position is a decimal point.

The eleventh through the thirteenth positions contain the amendment number which denotes the sequence of actions planned to occur within the fiscal year (FY) identified in the first two positions of the IPMIS Number.

All planned new awards are to contain the amendment number 000 , whether they are initiated in a Headquarters or field office. All planned modification actions initiated in a Headquarters office (excluding procurement operations) are to contain the numbers in sequence from .001 through .499. All field locations and Headquarters office of Procurement Operations are to use the amendment numbers in sequence from .501 through .999. Remember the amendment starts over at .001 or .501, depending upon your location, at the beginning of each new fiscal year. The number .500 is never to be used.

5. PROJECT MANAGER

Enter the name of the individual in the initiating office who is authorized to act as project manager. Enter the last name first, followed by first name and middle initial. Lo not 1nclude Mr., Dr., Mrs., Ms., or any other title. If the project manager has not been designated, enter the name of the individual most familiar with the plan. The complete name may not exceed 24 characters. A valid example is BOOHER, CORDA A.

6. OFFICE CODE

Enter the eight-character alphanumeric code that identifies the initiating office for this action. An example of a valid OFFICE CODE is: FE-33100. This code is comprised of: The major organizational 
element (positions 1 and 2), a dash (position 3) and the internal organizational breakdown (positions 4-8). If there is a decimal point in an office code, enter the code on the form without the decimal point.

8. TITLE

Enter the full title or subject statement which describes the action (i.e., provision of product or service) planned or being taken. The maximum field length is 180 characters. An example of a valid TITLE is: CALCULATE THE COAL RESERVE BASE IN COLORADO.

11. PRODUCT OR SERVICE (for Procurement/Acquisition Actions Only)

Enter the four-character alphanumeric Federal Procurement Data System (FPDS) code to identify the type of product or service associated with an award action. Do not use the codes on the back of DOE-F-4200.6 because they are no longer valid. Use the codes in the revised Table of Valid Product or Service codes in APPENDIX C. A more specific code than those contained in APPENDIX $C^{\prime}$ may be entered, if desired. Refer to the FPDS Reporting Manual or the Miscellaneous IPMIS Tables Index for the specific code. Y299 is an example of a valid code. Leave this field blank when completing a plan to modify an existing award.

14. PLANNED AWARDING OFFICE

Enter the two-character code to identify the planned awarding office. For example, 01 is a valid code. See back of form for codes. Leave this field blank when completing a plan to modify an existing award.

\section{EXTENT OF COMPETITION}

Enter the two-character code to indicate whether a planned action is to be competitive or non-competitive and the extent of that competition. For example, HA is a valid code. See back of form for codes. Notice that the list of available codes in the Procurement Series has been reduced. If desired, a more specific code may be entered by referring to the Miscellaneous IPMIS Tables Index for the specific code. Leave this field blank when completing a plan to modify an existing award.

\section{PR INITIATION DATE}

Enter the date the Procurement/Financial Assistance Request (PR), (DOE FORM PR 799 series) is expected to be fully completed (together with all attachments), approved, authorized, funded (if applicable), and released from an initiating office. Fur example, the date October 1,1980 , is to be entered as 100180 .

20. INAME

If the award is non-competitive, enter the name of the awardee as it appears in the DOE Standard Awardee Identification File. A valid 
example is "PENNSYLVANIA STATE UNIV" (without a period). The maximum field length is 30 characters. Leave this field blank when completing a plan to modify an existing award.

Enter the estimated total face value (Government Share) of the award, regardless of the funding obligation schedule. Enter the amount in whole dollars. Round the dollar amount to the nearest whole dollar. When planning a modification action to increase the scope of a procurement or financial assistance instrument, enter the amount of the increase only in the Government Share. A computer program will maintain a running total by adding this GOVT SHARE to the sum of the basic award and all previous modification actions.

The system will reject zero dollar plans (plans with no dollars), and plans with negative dollars. Therefore do not enter a zero in this field, or a minus figure, and do not leave it blank.

The AWARD VALUE - GOVT SHARE must be equal to the sum of Current FY Total (Item 30), plus all future (incrementa1) funding, plus consideration in kind. Future funding and consideration in kind are not specified anywhere else on the form.

24. AWARD VALUE - TOTAL

If the award is to be cost-shared by the awardee, add to the amount entered in item 23 (Government share) the amount the awardee is responsible to contribute and enter the total in item 24 . If the award is not to be cost-shared by the awardee, the amount entered in Total (1tem 24) must equal the duuuul entered in Covcrnment Share (Item 23). Do not leave blank. When planning a modification action to increase the scope of a procurement or financial assistance instrument, enter only the amount of the increase in the Total.

The total is entered in whole dollars. Round the dollar amount to the nearest whole dollar.

\section{APPROPRIATION SYMBOL}

Leave blank in all cases.

\section{FUNDING SOURCE - CURRENT FY B\&R NUMBER}

Enter the nine-digit Budget and Reporting ( $B \& R)$ Number which is used for reporting financial data in the fiscal year shown in the IPMIS NUMBER, item 4 above. Refer to instructions issued by the Controller. If the valid $B \& R$ Number is unknown, enter a valid two-position Headquarters initiating office code from the list in APPENDIX A. Use DOE-F-4200.7 to provide supplemental information if there are more than three $B \& R$ Numbers or if there is to be incremental funding during the current fiscal year. 
28. FUNDING SOURCE - CURRENT FY \$ AMOUNT

For each $B \& R$ Number or Headquarters initiating office code entered in item 27 above, enter the respective dollar amount. The amount should be entered in whole dollars. Round the dollar amount to the nearest whole dollar. Do not leave blank.

29. FUNDING SOURCE- CURRENT FY FROM DOE-F-4200.7

If DOE-F 4200.7 was used to provide supplemental information to item 27 and 28 above, enter in item 29 on DOE-F-4200.6 the amount entered in item' 8 on DOE-F-4200.7, ("the Total Dollar Amount Both Columns (7)").

30. FUNDING SOURCE - CURREN'I FY TOTAL

Enter the total of all dollar amounts from items 28 and 29 above. 
PART B - Detailed Instructions for Completing DOE-F 4200.7

The DOE-F-4200.7 contains nine different data fields. Instructions for completing each data field are given below in the same numerical sequence as they appear on the form

\section{INITIAL/UPDATE}

Because the DOE-F-4200.7 is always used to supplement a DOE-F-4200.6 and is never to exist alone, check the INITIAL/UPDATE block on the DOE-F4200.7 exactly as it was checked on the DOE-F-4200.6. That is, if the DOE-F-4200.6 was checked INITIAL, also check INITIAL on the accompanying DOE-F-4200.7.

3. IPMIS NUMBER

Enter the exact 13-character IPMIS Number on DOE-F-4200.7 that was entered on the accompanying DOE-F-4200.6 (I tem 4).

5. MONTH

If funding is to be provided in increments during the current fiscal. year, enter the two digit equivalent of the month in which each increment will occur. For example: If funding is to be quarterly, October 1981, January, April and July 1982, enter the first increment on DOE-F-4200.6 and enter the next three increments on DOE-F-4200.7. Use month digits as follows: 01, 04, 07 .

6. B\&R NUMBER

This item is to be completed if one of the following conditions exists:

- If there are more than three $B \& R$ Numbers or Headquarters initiating office codes. (The DOE-F-4200.6 cannot accommodate more than three $B \& R^{\prime} s_{.}$)

- If there is to be incremental funding action within the current fiscal year.

Enter the nine-digit Budget and Reporting ( $B \& R$ ) Number which is used for reporting financial data in the fiscal year shown in the IPMTS NUMBER, item 4, above. Refer to instructions issued by the Controller If a valid $B \& R$ Number is not known, enter a valid Headquarters initiating office code from the list in APPENDIX A.

7. \$ AMOUNT

For each $B \& R$ Number. or headquarters initiating office code entered in item 6 , enter the respective dollar amount. The amount should be entered in whole dollars. Round the dollar amount to the nearest whole dollar. 
8. TOTAL LOLLAR ARIUUNT BUTHE LULUMAS (7)

Enter the total of all dollar amounts in both \$ AMOUNT columns, item 7, This is the dollar amount which is to be entered on DOE-F-4200.6, item 29.

12. LENDER NANIE

If this is a Loan or Loan Cuarantee, enter the name of the financial institution making the loan to the planned awardee. The maximum field length is 30 characters.

13. LOAN VALUE (TOTAL)

If this is a Loan or Loan Guarantee, enter the total value of the loan amount. Enter the amount in whole dollars. Round the dollar amount to the nearest whole dollar.

14. GUARANTEE VALUE (GOVT)

If this is a Loan Guarantee, enter the total vaiue of the amount planned to be guaranteed by the Government. Enter the amount in whole dollars. Round the dollar amount to the nearest whole dollar. 


\title{
SECTION 3
}

\author{
FIELD WORK PACKAGE PROPOSAL AND AUTHORIZATION SYSTEM
}

\section{(WPAS) SUMMARY PLANS}

Part A - Detailed Instructions for Completing DOE-F-4200.6

Offices that authorize procurement work to contractors through the use of the Field Work Package Proposal and Authorization System are to submit WPAS Summary Plans. Submit a separate WPAS Summary Plan for each WPAS contractor. See Appendix B1/for the 11st of WPAS contractors, and Appendix B2/ for the list of "WPAS-like" contractors.

1. INITIAL/UPDATE

Enter an $X$ in the box to the right of INITIAL.

2. PROCUREMENT / FINANCIAL ASSISTANCE

Enter an $\mathrm{X}$ in the box to the right of PROCUREMENT.

4. IPMIS NUMBER

Enter the 13-character code which uniquely identifies this procurement action. This number is comprised of four parts: the fiscal year of the planned new award, the initiating organization's register number, a decimal point, and the appropriate contractor's "Vendor Code". An example of a valid IPMIS NUNBER IS 81FE12345.ANL.

The firot and oocond positions contain the last two digits of the fiscal year of the planned new award and must be equal to, or greater than, the current year.

The third through ninth positions contain the intiating organization's register number which consists of the initiating organizational code and a unique serial number. The organizational register number is controlled within each secretarial or staff office, operations office, project office, power administration, regional office, energy research center or other equivalent field level organization.

The tenth position is a decimal point.

The eleventh through the thirteenth positions contain the appropriate contractor's "Vendor Code." Select the code which applies from the list of WPAS contractors contained in APPENDIX $\mathrm{B} 1 /$ and $\mathrm{B} 2$ /. 


\section{PROJECT MANAGER}

Enter the name of the individual in the initiating office who is authorized to act as project manager. Enter the last name first, followed by first name and middle initial. Do not include Mr., Dr., Mrs., Ms. or any title. If the project manager has not been designated, enter the name of the individual most familiar with the plan. The complete name may not exceed 24 characters. A valid example is BOOHER, CORDA A.

6. OFFICE CODE

Enter the eight-character alphanumeric code that identifies the initiating office for this action. An example of a valid OFFICE CODE is: FE-33100. This code is comprised of three components: the major organizational element (positions 1 and 2), a dash (position 3 ) and the internal organization breakdown (position 4-8). If the re is a decimal point in an office code, enter the code without the decimal point.

8. TITLE

Enter "WPAS Summary Plan."

11. PRODUCT OR SERVICE

- Leave Blank.

14. PI.ANNF. AWARDING OFFICE

Leave Blank.

15. EXTENT OF COMPETITION

Leave Blank.

19. PR INITIATION DATE

Leave Blank.

20. NAME

Leave RTank.

23. AWARD VALUE - GOVT SHARE

Leave Blank.

24. AWARD VALUE - TOTAL

Leave Blank. 
25. APPROPRIATION SYMBOL

Leave Blank.

27. FUNDING SOURCE - CURRENT FY B\&R NUMBER

Enter in item 27 the two-position headquarters initiating office code for each contributing program office: See APPENDIX A for a table of valid initiating office codes. It is not necessary to enter B\&R Numbers for WPAS.

28. FUNDING SOURCE - CURRENT FY \$ AMOUNT

Cite on the WPAS Summary Plan the Current FY Dollar Amount in whole dollars directly across from the contributing office's two-position initiating office code which was entered in the Current FY B\&R Number field (Item 27).

29. FUNDING SOURCE - CURRENT FY F'ROM DOE-F-4200.7

If DOE-F-4200.7 was used to provide supplemental information to items 27 and 28 above, enter in item 29 on DOE-F-4200.6 the amount entered in item 8 , on DOE-F-4200.7 (the total Dollar.Amount in Both Columns (7)").

30. FUNDING SOURCE - CURRENT FY TOTAL

Enter the total of all dollar amounts entered in items 28 and 29 above to be funded in the FY shown in Item 4. Round all dollar amounts to the ncarest whole dollar. 
PART B - Detailed Instructions for Completing DOE-F-4200.7

When a field activity completes a WPAS Summary Plan for a transaction to be funded by more than three program offices, the DOE-F -4200.7 must be used to enter the additional program office codes and their contributing dollar amounts. Instructions for completing the applicable fields are given below.

i. INITIAL/UPDATE

Because the DOE-F-4200.7 is always used to supplement a DOE-F-4200.6 and is never to exist alone, check this block, exactly as it is checked on the LOE-F-4200.6. That is, if the DOE-F-4200.6 is checked INITIAL, check INITIAL on the accompanying DOE-F-4200.7.

2. IPMIS NUS:BER

Enter here the exact 13-character IPMIS NUMBER that was input on the accompanying DOE-F-4200.6 (Item 4). which this DOE-F-4200.7 form is supplementing.

5. HONTH

Leave Blank.

6. B\&R NUMBER

This item is to be completed on WPAS Summary Plans if the number of funding program offices exceeds three. (The DOE-F-4200.6 cannot accommodate more than three $B \& R$ numbers.) Cite here the twoposition initiating office code for each contributing program office. See APPENDIX A for a valid table of initiating office codes.

\section{7. \$ AMOUNT}

Cite the current FY $\$$ AMOUNT in whole dollars directly across from each contributing office's two-position initiating office code entered in B\&R NUMBER (Item 6).

8. TOTAL DOLLAR ANOUNT BOTH COLUMNS (7)

Enter the total of all dollar amounts in both \$ amounts columns, item 7 . Enter in item 8 on DOE-F -4200.7 the dollar amount entered in item 29 on DOE-F-4200.6.

12. LENDER NAME

Leave Blank. 
13. LOAN VALUE (TOTAL)

Leave Blank.

14. GUARANTEE VALUE (GOVT)

Leave Elank. 
PART C - UPDATING WPAS SURMARY PLANS

Refer to SECTION 4, UPDATING OR CORRECTING PLANS FOR NEW AWAPDS AND MODIFICATIONS TO EXISTING AWARDS, for instructions to update or correct WPAS Summary Plans. 


\section{SECTION 4}

\section{UPDATING OR COR.RECTING PLANS FOR NEW AWARDS AND NODIFICTIONS}

\section{TO EXISTING AWARDS}

This mechanism has been established to enable a user to correct an IPMIS form which has already been entered into the IPMIS system and has been found to have incorrect data in one or several data fields.

\section{Please Note:}

If it is possible to determine with certainty that the initial form has not been entered into the IPMIS data base, that initial form may be altered or corrected in any manner without using the correction procedure outlined in this section. Leave Item 1 INITIAL and do not change to UPDATE.

Use the same updating procedures described on the following pages to correct DOE-F-4200.6 and DOE-F-4200.7 which were completed for WPAS Sunmary Plans.

PART A - Detailed Instructions for Correcting (DOE-F-4200.6)

\section{INITIAL/UPDATE}

Enter an $X$ in the box to the right of UPDATE. This applies whether this update is to correct an initial plan for a new award, an initial plan to modify an existing award, or a WPAS Summary Plan.

\section{PROCURENENT / F INANCIAL ASS ISTANCE}

Enter an $X$ in the box to the right of PROCUREMENT if this form covers a procurement or acquisition action which includes: Contracts, Special Research Contracts, Task Order/Project Agreements, Delivery Orders, and Interagency Agreements.

Enter an $X$ in the box to the right of FInIANCIAL ASSISTANCE if this form covers any of the following types of financial or federal assistance: Cooperative Agreements, Grants, Interest Agreements, Loans, Loan Guarantees, Price Support Agreements and Subsidy Agreements.

4. IPMIS NUMBER

Enter the same IPNIS NUMBER that was entered on the original (i.e., INITIAL) DOE-F-4200.6. Be sure to enter the same amendment number (i.e., if 000 was entered on INITIAL input, enter 000 on UPDATE input). 
$5 ., 6 ., 8 ., 11 ., 14 \cdot, 15:, 19 ., 20$.

Enter data in these fields only if the data was incorrect or has changed from that entered on the initial form. For example, if only the EXTENT OF COMPETITION was incorrect or has changed, enter data only in item 15.

FINANCIAL SECTION - Items 23., 24., 27., 28., 29., and 30. There are unique interrelating edits among these elements. Therefore, if a change is made to any one element, all the other elements in this section must also be completed, even if the data does not change for these elements. For example: a change in the Government Share (Item 23) may occur without changing the B\&R Number (Item 27). Even so, when this situation occurs, 1 t is still necessary to repeat the data in the B\&R (Item 27).

To make a change to an individual data element within the Financial Section, enter the correct value and disregard the value entered incorrectly on the initial DOE-F-4200.6. For example: If the initial Government Share amount was 200,000, and the correct amount should have been 400,000, enter 400,000. Enter all dollar amounts in whole dollars, rounded to the nearest whole dollar.

\section{AWARD VALUE - GOVERMMENT SHARE}

Complete this item if any other item in the Financial Section changes, even if the dollar amount for this item remains the same as it was on the initial DOE-F-4200.6. Enter all dollar amounts in whole dollars, rounded to the nearest whole dollar.

24. AWARD VALUE - TOTAL

Complete this item if any other element in the Financial Section changes, even if the dollar amount for this item is the same as it was on the initial DOE-F-4200.6. Enter all dollar amounts in whole dollars, rounded to the nearest whole dollar.

NOTE: Since the TOTAL is equal to the sum of the GOVERNMENT SHARE (Item 23) plus the awardee share, when the action is cost-shared, or the TOTAL is equal to the GOVERNMENT SHARE, when no costsharing is involved, any change in the amount of the GOVERNMENT SHARE requires a change to the TOTAL.

25. APYROPRIATION SYMMBOL

Leave blank.

27. B\&R NUMBER

Complete this item when any other element in the Financial Section Changes, even if the value is the same as it was on the initial DOE-F -4200.6 . 
28. \$ AMOUNT

Complete this item if any other element in the Financial Section changes, even if the dollar amount is the same as it was on the initial D0E-F-4200.6. Enter the dollar amount in whole dollars, rounded to the nearest whole dollar.

NOTE: The dollar amounts entered in Item 28 are components of the amount entered in CURRENT FY TOTAL (Item 30) and of the dollar amount entered in GOVERNMENT SHARE (Item 23); therefore, if a change is made to this element a change must also be made to the dollar amounts in Items 23,24 , and 30 .

29. CURRENT FY FROM DOE-F-4200.6

If the initial DOE-F-4200.6 contained data in this field, this element must be completed if any other element in the Financial Section is changed. If this element was blank on the initial DOE-F-4200.6, leave it blank on the updated DOE-F-4200.6, unless the change 1 s to add additional B\&R NUMBERS and dollar amounts which exceed the three spaces on the DOE-F-4200.6. In that case, a DOE-F-4200.7 must also be completed, and the total dollar amount from that form brought forward and entered in Item 29 on DOE-F -4200.6

30. CURRENT FY TOTAL

Complete this 1 tem if any other element in the Financial Section changes, even if the dollar amount for this item is the same as it wac on the initial DOE-F-4200.6. Enter all dollar amounts in whole dollars, rounded to the nearest whole dollar. 
PART B. Detailed Instructions for Correcting DOE-F-4200.7

1. INITIAL/UPDATE

Because the DOE-F-4200.7 is always used to supplement a DOE-F-4200.6 and is never to exist alone, the INITIAL/UPDATE block is to be checked here, exactly as it is checked on the DOE-F-4200.6. That is, if the DOE-F-4200.6 is checked UPDATE. Also check UPDATE on DOE-F-4200.7

3. IPMIS NUMBER

Enter in item 3 the exact 13-character IPMIS Number that was input in item 4 on the accompanying DOE-F-4200.6.

$5 \cdot, 6 ., 7 \cdot, \varepsilon$

If any one element is changed, all data elements must be reentered and adjusted accordingly. If there is no change to any data element leave all blank.

12. LENDER NANIE

Enter data only if it is different from that which was entered on the initial DOE-F-4200.7

13. LOAN VALUE (TOTAL)

If there is no change, leave blank.

When making a change to this data element, enter the correct value and disregard the value entered incorrectly on the initial DOE-F4200.7 form. Enter all dollar amounts in whole dollars, rounded to the nearest whole dollar.

NOTE: If a change is made to item 13, reenter the amount and make any necessary adjustment in item 14 (Guarantee Value (GOVT)).

11. GUAPANTEE VALUE (GOVT)

If no change is made, leave blank.

If a change is made to this data element, enter the correct value and disregard the value entered incorrectly on the initial DOE-F4200.7. Enter ali dollar amounts in whole dollars, rounded to the nearest whole dullar.

NOTE: If a change is uilde Lo 1tem 14, reenter the amount and make any necessary adjustment in item 13. (LOAN VALUE (TOTAL)). 


\section{SECTION 5}

CANCELLATIONS

PART A - Detailed Instructions for completing DOE-F-4200.8

DOE-F-4200.8 contains four different data fields. Use this form to cancel an existing plan. A total of 10 records can be cancelled on on'e form. Instructions for completing. each data field are given. below in the same numerical sequence as they appear on the form.

1. IPMIS NUMBER

Enter the same IPNiS Number that appears on the plan, DOE-F-4200.6. Be sure to enter the correct amendment.

2. $189 /$ TAPS NO

Leave blank.

3. CANCELlation DATE

Enter the date the plan was cancelled using the following format:

MI DD YY. For example, enter October 1, 1981, as 100181 .

4. REASON

Enter the one character code indicating the reason that the plan was cancelled. Cancellation reason codes may be found at the bottom of DOE-F-4200. 8 . 
APPENDIX A

\section{INITIATING ORGANIZATIONS}

Code Meaning

Headquarters

CE

Assistant Secretary for Conservation and Renewable Energy

$\mathrm{CP}$

Assistant Secretary for Congressional, Intergovernmental, and Public Affairs

DP

Assistant Secretary for Defense Programs

EI

Energy Information Administration

EP

Assistant Secretary for Environmental Protection, Safety, and Emergency Preparedness

ER

FE

HG

Director of Energy Research

Assistant Secretary for Fossil Energy

Director of. Hearings and Appeals

Assistant Secretary for International Affairs

Assistant Secretary for Management and Administration

MA

$\mathrm{NE}$

Assistant Secretary for Nuclear Energy

Director of Policy, Planning, and Analysis

$\mathrm{RC}$

Federal Energy Regulatory Commission

RG

Economic Regulatory Administration 


\section{$\underline{\text { APPENDIX B }}^{1 /}$}

\section{LIST OF WPAS CONTRACTOR FACILITIES}

\section{Facility}

1. Amarillo (Pantex) Plant

2. Ames Laboratory

3. Argonne National Laboratory

4. Bates Linear Acceleratory Facility

5. Bettis Atomic Power Laboratory

6. Brookhaven National Laboratory

7. Center for Energy \& Environmental Research

8. Comparative Animal Research Laboratory*

9. Courant Mathematics and Computer Laboratory*

10. Davis Radiobiology Laboratory

11. Energy Technology Engineering Center

\begin{tabular}{|c|c|c|c|}
\hline Contractor & $\begin{array}{c}\text { Outlay Program } \\
\text { Manager } \\
\end{array}$ & $\begin{array}{l}\text { Register } \\
\text { Number }\end{array}$ & $\begin{array}{c}\text { IPMIS } \\
\text { VENDOR CODE }\end{array}$ \\
\hline $\begin{array}{l}\text { Mason \& Hanger Silas } \\
\text { Mason Co. }\end{array}$ & $\mathrm{DP}$ & DP00487 & ALM \\
\hline Icwa State University -. & ER & CHENG82 & AML \\
\hline Uriversity of Chicago & ER & CHENG 38 & ANL \\
\hline $\begin{array}{l}\text { Messachusetts Institute of } \\
\text { Technology }\end{array}$ & ER & ER03069 & $\mathrm{XBU}$ \\
\hline $\begin{array}{l}\text { Westinghouse Electric } \\
\text { Company }\end{array}$ & $\mathrm{NE}$ & PN00014 & IBU \\
\hline Associated Universities, Inc. & ER & $\mathrm{CH} 00016$ & BNL \\
\hline Ur.iversity of Puerto Rico & ER & OR01833 & QRR \\
\hline Ur.iversity of Tennessee & ER & OR00242 & OBU \\
\hline New York University & $E R^{* *}$ & ER03077 & UEF \\
\hline $\begin{array}{l}\text { Ur.iversity of California, } \\
\text { Davis }\end{array}$ & ER & SF00472 & RBU \\
\hline Rockwell International Corp & NE & SF00700 & PDQ \\
\hline
\end{tabular}




\section{Facility}

12. Extrusion Plant, Ashtabula

13. Fermi National Accelerator Laboratory

14. Fernald Feed Material Production Center

15. Fusion Plasma Research Center*

16. Grand Junction Facility

17. Hanford Engineering Development Laboratory

18. Hanford Production Operations

19. Hanford Production Operations

20. Idaho Falls Chemical Processing Plant

21. Idaho National Engineering Laboratory

22. Inhalation Toxicology Research Institute*

23. Kansas City Plant

24. Knolls Atomic Power Laboratory

25. Laboratory of Nuclear Medicine and Radiobiology

Contractor
RMI Company
University Research Assoc.,
Inc.
National Lead Company of
Ohio

University of Texas-Austin

Bendix Field Engineering

Corporation

Westinghouse Hanford

Rockwell Hanford Operations

United Nuclear Corp.

Exxon Nuclear Idaho, Inc.

$E G \& G$, Idaho

Lovelace Foundation for Medical Research

Bendix Corporation

General Electric Company

University of California

\section{Outlay Program}

Manager

DP

ER

DP

$E R * *$

ET53036

and

ET53043

NE

GJ01664

$\mathrm{NE}$

FF02 170

DP

DP

DP.

$\mathrm{NE}$

ER

DP

NE

ER
IPMIS

Vendor Code

NWJ

SLX

ORD

EZW

GFB

VKQ

LTC

CWZ

XsX

WTC 


\section{Facility}

26. Laboratory of Nuclear Science*

27. Lawrence Berkeley Laboratory

28. Lawrence Livermore National Laboratory

29. Los Alamos National Scientific Laboratory

30. Materials Research Laboratory*

31. MHD Component Development and Integration Facility

32. Mid-American Solar Energy Center, Minneapolis, Minnesota

33. MIT Plasma Fusion Center*

34. Mound Facility

35. MSU Plant Research Laboratory*

36. Nevada Test Site

37. Nevada Test Site

38. Nevada Test Site

\section{Contractor}

Massachusetts Institute of Technology

University of California

University of California

University of California

University of Illinois

Montana Energy and MHD

Research and Development Institute

Mid-American Solar Energy Center

Massachusetts Institute of Technology

Monsanto Research Corporation

Michigan State University

$\mathrm{EG} \& \mathrm{G}$, Inc.

Holmes \& Narver

Reynolds Electric \& Engineering Company

\section{Outlay Program Register IPMIS}

Manager

Number

Vendor Code

$\mathrm{ER} * *$

ER03069

DTC

ER

SFENG48

DP

SFENG48

WZJ

DP

ALENG36

LSL

$\mathrm{ER} * *$

ER01198

JLF

FE

ID01745

AZP

CE

$\operatorname{Cs} 30150$

RTC

ER

ET 51013

GTC

DP

DP00053

ALR

ER

ER01338

LBU

DP

NV01183

NVB

DP

NV0002D

NVD

DP

NV0041D

NVG 


\section{Facility}

39. Northeast Solar Energy Center Boston, llassachusetts

40. Notre Dame Radiation Laboratory

41. Nuclear Physics Laboratory*

42. Oak. Ridge Associated Universities

43. Oak Ridge Gaseous Diffusion Plant

44. Oak Ridge National Laboratory

45. Pacific Northwest Laboratories

46. Paducah Gaseous Diffusion Plant

47. Pinellas Plant

48. Portimouth Gaseous Diffusion Plant

49. Princeton Plasma Physics Laboratory

50. Rocky Flats Weapons Plant

51. Sandia Natjonal Laboratories

52. San Francisco Laboratory of Radiobiology

53. Savannah River Ecology Laboratory

54. Savannah River Laboratory

\begin{tabular}{|c|c|c|c|}
\hline Contractor & $\begin{array}{c}\text { Outlay Program } \\
\text { Manager } \\
\end{array}$ & $\begin{array}{l}\text { Register } \\
\text { Number }\end{array}$ & Vendor Code \\
\hline Northern Energy Corporation & $\mathrm{CE}$ & $\operatorname{cs} 30149$ & OTC \\
\hline University of Notre Dame & ER & ER00038 & YGU \\
\hline University of Washington & ER & ER013:8 & OCE \\
\hline $\begin{array}{l}\text { Oak Ridge Associated } \\
\text { Universities, Incorporated }\end{array}$ & ER & OR00033 & ORH \\
\hline Union Carbide Corporation & $\mathrm{NE}$ & ORENG26 & JTC \\
\hline Union Carbide Corporation & ER & ORENG26 & ONL \\
\hline Battelle Memorial Institute & $\mathrm{NE}$ & RL01830 & DZR \\
\hline Union Carbide Corporation & $\mathrm{NE}$ & ORENG2 6 & $\mathrm{XTC}$ \\
\hline General Electric Company & $\mathrm{DP}$ & DP00656 & ITC \\
\hline Goodyear Atomic Company & $\mathrm{NE}$ & OR00001 & ORB \\
\hline Princeton University & ER & СH03073 & QGU \\
\hline Rockwell International & $\mathrm{DP}$ & DP03533 & YEC \\
\hline Sandia Corporation & $\mathrm{DP}$ & DP00789 & ALS \\
\hline University of California & ER & SF01012 & SBU \\
\hline University of Georgia & ER & SR00819 & WBU \\
\hline E. I. Dupont de Nemours & DP & SR00001. & DBU \\
\hline
\end{tabular}




\section{Facility}

55. Savannah River Plant

56. Shippingport Atomic Power Station

57. Solar Energy Research Institute

58. Southern Solar Energy. Center Atlanta, Georgia

59. Stánford Linear. Accelerator Facility

60. University of Rochester Biomedical Laboratory

$\stackrel{\omega}{\circ}$ 61. University of Utah Radiobiology Laboratory

62. Western Solar Utilization Network, Portland, Oregon

63. Wright Nuclear Structures Laboratory*

64. Y-12 P1ant
I. I. Dupont de Nemours

$$
\& \text { Company }
$$

Juquesne Light Company

-fidwest Research Institute

Southern Solar Energy Center

Stanford University

University of Rochester

University of Utah

Western Solar Utilization Network

Yale University

Union Carbide Corporation Manager

DP

NE

ER

ER

$\mathrm{ER} * *$

DP
CHOC178

$\operatorname{cs} 30166$

SF00515

EV 03490

EV00119

$\operatorname{cs} 30159$

ER03075

WXE

IPMIS Vendor Code

SRB

AGU

TGF

CTC

SFL

GBU .

JBU

PTC

ORENG26

QEC

*Indicates contractor facilities which did not meet all criteria for consideration as WPAS contractors but were justified for other reasons to be designated as WPAS contractors.

**Indicates contractor facilities which, while not assigned to an Outlay Program Manager, receive the major portion of funding from the Outlay Program Manager listed. 


\section{APPENDIX $\mathrm{B}^{2 /}$}

\section{LIST OF "WPAS-LIKE" CONTRACTOR FACILITIES}

The contractors listed below are not included in the WPAS order as operating under the Field Work Package Proposal Authorization System and are therefore not in the list of WPAS contractors in APPENDIX B1/. However, for purposes of reporting planning data to the IPMIS system, any planning forms for these contracts should be completed in the same manner as planning forms are completed for the WPAS contracts, using the instructions for WPAS transactions, Section 3, of the planning guide. That is, the dollars should only be reported at the summary level, and the Eleventh through thirteenth positions of the IPMIS number (Item No. 4, DOE-F-4200.6) must contain the appropriate contractor's "Vendor Code."

\section{Contractor}

Los Alamos Construction, Inc.
Register Number

DP01357

DP00090

OR 05663

OR06067

RL01698

RL01837

RL00687

RL 02320

OR02908

CHENG 92
IPMIS

Vendor Code

ALL

ALZ

ORK

$\operatorname{MRX}$

IIE

ELY

RLT

TMA

$\mathrm{ZZO}$

Battelle Memorial Institute

HVJ 
APPENDIX C

PRODUCT OR SERVICE CODES

Code Meaning

R\&D Services

$\begin{array}{ll}\text { AG10 } & \text { Coal } \\ \text { AG20 } & \text { Gas } \\ \text { AG30 } & \text { Geothermal } \\ \text { AG40 } & \text { Hydro } \\ \text { AG50 } & \text { Nuclear } \\ \text { AG60 } & \text { Fetroleum } \\ \text { AG70 } & \text { Solar } \\ \text { AG80 } & \text { Conservation of Energy } \\ \text { AG90 } & \text { Other Energy } \\ \text { AH90 } & \text { Environment } \\ \text { AJ10 } & \text { General Science and Technology } \\ \text { AZ10 } & \text { Other Research and Development }\end{array}$

Services Other Than R\&D

J099

K099

L099

M199

N099

R119

R129

R219

R399

$\mathrm{R} 498$

R499

R599

S119

5299

Y 299

Z299

1195

3695

3895

4470

4540

5680

5999

6150

6695

6850

7010

7030

7045

9160

9999

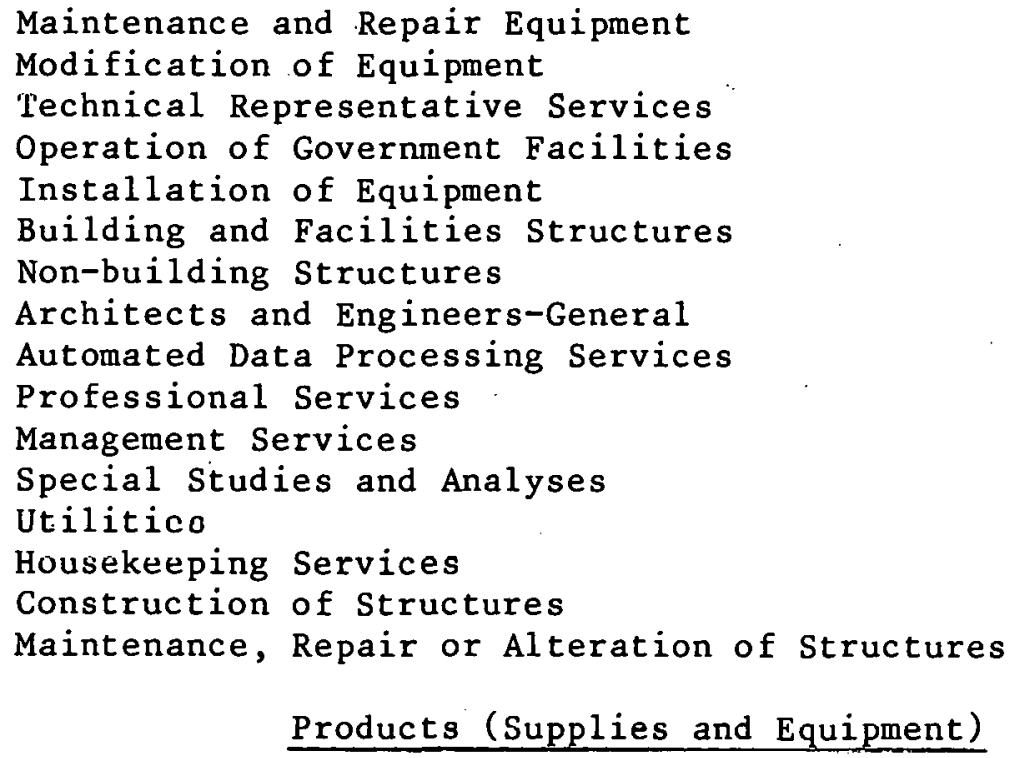




\section{UNITED STATES}

DEPARTMENT OF ENERGY

WASHINGTON, D.C. 20585

OFFICIAL BUSINESS

PENALTY FOR PRIVATE USE, $\$ 300$
POSTAGE AND FEES PAID

U.S. DEPARTMENT OF ENERGY

DOE 350

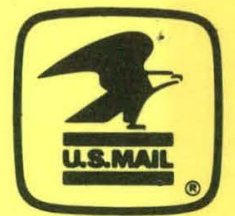

THIRD CLASS MAIL 